\title{
12 \\ Can we Require Legislatures to State the Reasons for their Legislative Decisions?
}

Kees Waaldijk

1. Giving reasons for legal declsions seems to be a fairly general practice in law and a fairly general principle of law. As a principle it has been developing most notably in the field of administrative law. In 1969 comparative research showed that in all countries having a Code of Administrative Procedure this code contained some requirement to give reasons (Wiener 1969: 787). The same research showed that in most other countries the giving of reasons was requitred by special statutes or by judge-made law for many categories of administrative acts (1969: 789-793). An important transnational formulation of the principle can be found in Resolution 77/31, "On the protection of the individual in relation to the acts of the administrative authorittes", adopted on 28 September 1977 by the Committee of Ministers of the Council of Europe. Item IV of the Appendix to this Resolution reads as follows:

"Where an administrative act is of such nature as adversely to affect his rights, liberties or interests, the person concerned is informed of the reasons on whtch it is based. This is done either by stating the reasons in the act, or by communicating them, at his request, to the person concerned in writing within a reasonable time."

The obligation to give reasons for judiclal decistons has been established even stronger. See for example Article 121 of the Dutch Constitution. In fact, judicial decisions consist of little else but reasons for the dictum in the last paragraph.

In general, legal decisions of private citizens need not be accompanied by statements of reasons. However, various exceptions to this rule have been created by law. See for example the duties of 
an employer who wants to terminate a contract. And in a recent case (HR 4 June 1982, NJ 1983, nr. 32) the Dutch Supreme Court has ruled that parents who refuse to give their minor child permission to marry, have to give their reasons for this refusal, because this refusal adversely affects a fundamental freedom of the child.

If thus the obligation to give reasons for legal decisions is so general that it not only binds judicial and administrative authorities, but also some private persons, what then about the position of legislative bodies? It is clear that statutes can adversely affect rights, liberties and interests. So at least one of the rationes behind obligations to give reasons also applies to legislative bodies. Nevertheless, in most countries an obligation for the legislature to give reasons for its legislative decisions is neither established nor discussed as a rule or principle of constitutiona1 law. However, it may be argued that at least in the Netherlands such a rule or principle is suggested by various direct and indirect sources of law, especially by the constitutional practice of accompanying legislative proposals with reasons.

So the question whether a legislature is required to state the reasons for its legislative decisions is debatable in law. The question however begs another question, which is of a less normative and more empirical and analytical character: Can we require legislatures to state reasons? Giving reasons for statutes seems more problematic than giving reasons for judicial or administrative decisions, because of the collective, political, unlimited, clustered and continuous character of legislative decisions. It is this problematic character of (primary) legislation in relation to a possible duty to give reasons, that forms the subject matter of this paper. I will try to analyse the five characteristics mentioned.

\section{Statutes as collective decisions.}

In writings on the interpretation of statutes it has frequently been noted that all talk about "legislative intention" is fictional, or at least problematic. One reason for that is, that most modern Western democratic "legislatures" consist of more than one body (one or two houses of parliament, sometimes plus a separate government) and that these legislative bodies consist of numerous in- 
dividual members. So if a legislature were required to state "its" reasons, difficulties would arise about whose reasons should be stated. Situations in which alle members of all parts of a legislature agree about both the content and the reasons, are rare. In situations where only a majority supports an enactment, the requirement to give reasons could be restricted to the reasons of that majority. These reasons could then be regarded as the reasons of the legislature. However, even in situations where a majority of legislators concur about the content of an enactment, the reasons for which they do so, may be different. Majority decisions may be reached on the basis of different minority reasons. Whose reasons should then be stated as the reasons of the legislature?

The same problem arises of course in collective courts. In some legal systems this problem is not permitted to appear: the court has to produce one collective opinion. The members of the court are forced into real or pretended consensus. In other legal systems courts are not required to produce collective opinions, not even majority opinfons. Dissenting judges may express their own reasons for concurring or dissenting with the majority decision. The court as such does not state "its" reasons.

In most Western democracies legislatures follow the second system. Preambles (that is the technical name for that part of a statute in which the reasons of the legislature for that statute are given) are extremely rare in Belgium, Luxembourg, France, Switzerland, the Federal Republic of Germany and the United Kingdom. And even in the Netherlands, where a preamble is constitutionally required in every Act of Parliament, most preambles do not say much more than that the Act is "desirable" or "necessary" (Waaldijk 1984: 410). Thus the members of the legislatures in these countries are not required to reach or pretend consensus about the reasons for an enactment. For those interested, no document containing the reasons of (the majority of) the legislature is avallable.

However, some documents come close to being guides to the reasons of the legislatures, for although legislative decisions may not be accompanied by statements of reasons, legislative proposals (Bills) generally are. In document-oriented cultures like the $\mathrm{Ne}-$ therlands this is done in explanatory memoranda (which, later on, 
are supplemented by parliamentary debates). In oral cultures like the United Kingdom the reasons of the proposers are first expressed in parliamentary debates (which sometimes are supplemented by explanatory memoranda). The reasons thus put forward by the proposers of the enactment may persuade a majority to support it. The same reasons may (or may not, as is the official doctrine in the United Kingdom) later be used by judges and other interpreters of the statute. However, these reasons are never formally adopted by (a majority of) the legislature. In general it is unknown whether these reasons represent the actual reasons of a majority of the legislature. Lengthy study of numerous concurring and dissenting opinions expressed during parliamentary debates may be needed to discover any consensus or dissent about the reasons for legislation. These difficulties for the interpreter emphasise how difficult it would be for the legislature if it were required to produce a collective "opinion" about the desirability or necessity of an enactment.

\section{Statutes as political decisions.}

Law-making is only one tool for a legislature to exert political power. Giving reasons for that law-making can be used as a separate tool for influencing citizens, judges, etcetera.

Therefore, legislatures may be tempted to put forward other than their actual reasons, or at least to tailor their reasoning to other political aims than supporting the enactment concerned. In particular, politicians may use legislative reasons for various symbolic and ideological purposes. Rethorn (1976: 310-313) and Kindermann (1979: 83-84), two West German authors, have pointed out that preambles have been used very frequently both in Nazi Germany and in East Germany, mainly for purposes of propaganda, they claim. The hypothesis may be put forward that preambles are mainly used by lawgivers who are anxious to establish or reinforce their authority. Further evidence for this hypothesis may be found in many new constitutions of the last two centuries, e.g. in France and (West) Germany, (Rethorn 1976: 308), In major constitutional Acts of the British Parliament (Erskine May 1983: 493) and in regulations and directives of the Commission and the Council of the European Communities (by force of the duties to give reasons contained in the 
treaties establishing these Communities, especially Article 190 of the EEC-Treaty), all of which have preambles in them. As we have seen, most ordinary statutes enacted by legislatures with an established authority in Western democracies do not contain preambles.

of course (mis)use of preambles for various political purposes is possible even when there is no requirement to accompany statutes with preambles. However, the possibility of political misuse of preambles, and especially the possibility that a legislature will put forward other than its actual reasons, should make us sceptical when considering any requirement for legislatures to give reasons.

The possibility of discrepancles between the real reasons and the reasons given also exists where courts are required to give reasons for their decisions. However, judges are less likely to be tempted to put forward false reasons. This difference between judges and legislators will be partly explained in the following paragraph.

\section{Statutes as unlimited decisions.}

What use would a requirement to give reasons be, if any reason given would be acceptable? None, it seems. The requirements to give reasons for administrative and judicial decisions make sense, because these decisions and the reasons on which they are based may be reviewed by (higher) authortties on their conformity with rules and principles of law. Simllarly, when the Dutch Supreme Court introduced the requirement to give reasons for a parental refusal to marry, this requirement only made sense because in the same decision the court ruled that such a refusal is only lawful if it is not unreasonable (HR 4 June 1982, NJ 1983, nr. 32). In other words, the - formal - requirement to give reasons is only useful in relation to - material - rules outlawing particular (e.g. unreasonable or discriminatory) reasons.

The problem then is that legislation is hardly subject to any material rule: legislatures can lawfully legislate for any reason. This is known in constitutional law as the legislative supremacy or soverelgnty of parliament. And although in many countries inroads on this supremacy have been made (notably in the United States and the Federal Republic of Germany, to a lesser extent in France and 
the Netherlands, and to a still very limited extent in the United Kingdom), the rules contained in constitutions and international texts set only very few limits to the powers of the legislatures. There is not much "supra-legislative law" or "ubergesetzliches Recht". Legislatures can still legislate for almost any reason.

The analogy with supreme courts is not complete, for although supreme courts (just like supreme legislatures) are not subject to any superior control, unlike supreme legislatures they are fully subject to the body of law they are supposed to enforce.

This means that legislatures have hardly any focus for their statement of reasons, whereas judicial and administrative authorities can focus their reasoning on the rules to which their decisions and their reasons have to conform.

\section{Statutes as clustered decistons.}

Most administrative and judicial decisions are concerned with one "digital" point only (conviction, acquittal; annulment; granting, refusing or withdrawing a licence; etcetera). This makes it possible to focus the reasoning on that one point. The reasoning can be one line of argument with one conclusion: the actual deciston.

On the contrary, most legislative decisions form a whole cluster of provisions (primary rules, rules of enforcement, rules of procedure, definitions, transitional provisions, etcetera). That makes it very difficult for the reasoning to be focussed. When required to state its reasons, a legislature therefore will either give only general reasons for the general desirability or necessity of the enactment, or it will try to develop a separate line of argument for each and every (element of a) provision. Or alternatively, the legislature will not know how to conform to the requirement to give reasons, unless this requirement is made more specific.

\section{Statutes as continious decisions.}

Two aspects may be distinguished in each legislative decision: (a) the decision to enact the statute concerned and (b) the statute which is enacted. Once the statute is enacted, the decision to enact is only something which happened in the past. The statute 1tself however has a continuous character: it is "always speaking" 
(at least from its commencement until its repea1).

The same distinction can be made in most administrative and judicial dectstons too. However, there the continuous aspect of the decision is less important, mainly because it will only be operative for the person concerned during a relatively small period.

The distinction has implications where reasons are concerned. At the time of enactment the reasons for legislation may be supposed to cover both the unique and the continuous aspect of the decision. However, after a while the reasons for the continuous statute may start to change; or, to be more precise, the facts and desires constituing these reasons may change or even disappear. The wisdom that people and societies and their knowledge and desires, frequently change, has even led to a Latin maxim about the relationship between law and its reasons: cessante ratione legis cessat ipsa lex (when, or where, the reason of a law ceases, the law itself ceases). Opinions vary as to the degree to which this maxim is applicable to legislation and other forms of law (see Bennion 1984: 345-346). The maxim suggests that only the historical reasons for enacting are relevant. It is a fact however, that the functions of statutes change over time, and that legislators take these changes into account. The reasons for not repealing may well be very different from the historical reasons for enacting.

If it were required that the reasons for legislation should be stated by the legislature, it would not suffice to state only the reasons for every enacting event. The giving of reasons should then be just as continuous as the statutes themselves: every now and again the (new) reasons for not repealing should be given.

If, on the other hand, the requirement to state reasons for legislation were restricted to the reasons for enacting, many important reasons for legislation (i.e. for not repealing existing statutes) would sti11 not be given.

7. The general theme in the preceding paragraphs is that there is no clear framework, in which reasons for legislative decisions can be given. It may be argued however, that such a framework is in the process of developing and being developed. This is partly due to the fact that legislation has become a frequent and regular form of 
legal decision-making ( such as adjudication and administration have been already for a longer time), and partly to the - related - growing concern among academic and other lawyers that legislation should be ruled by law too.

As to the collective character of legislation it should be noted that very many legislative decisions are in fact the decisions of one single body: a ministerial department. Legislative assemblies hard1y ever "legislate"; they just give their (more or less informed) consent to decisions of the administration. And so too, the political character of legislation is fading: most legislative decisions are merely "administrative".

At the same time the unlimited character of legislation is ever more taken away by a growing number of supra-legislative rules: constitutions, international treaties (especially in the fields of human rights and economic and technical cooperation), decisions of international bodies (especially those of the "supra-national" European Communities), unwritten principles of proper legislation, guidelines for legislative policy and "drafting", political ideals like deregulation, etcetera (Waaldijk 1985: 4-12). These bodies of rules also make it possible to distinguish between the different "decisions" contained in a clustered legislative decision. Thus, the reasoning of legislatures (i.e. the ministerial departments), rather than concentrating on the general desirabilfty of the statute, can now focus on the conformity of specific provisions of the statute to specific supra-legislative rules. And this can be done both at the time of enactment, and on every later occasion on which the statute, or one of its provisions, is challenged in parliament or before a national or international court. On all these occasions the responsible department can be required to explain why "its" decisions do not contravene superior (legal or semi-legal) rules.

We may conclude that it is becoming less problematic to require legislatures to state the reasons for their legislative decisions. And thus, it becomes possible for legislative decisions to conform to the same "rule of law" as administrative and judicial decisions: to be embedded in a system of rational argumentation for reasonable decisions. That may even be desirable. 
118

\section{References}

Bennion, F.A.R. (1984). Statutory interpretation. London.

Erskine May (1983). Treatise on The Law, Privileges, Proceedings and Usage of Parliament, Sir Charles Gordon, ed., Twentieth Edition. London.

Kindermann, H. (1979). Ministerielle Richt1inien der Gesetzestechnik. Berlin.

Rethorn, D. (1976). Verschiedene Funktionen von Präambeln. In J. Rödig, Hrsg. Studien zu einer Theorie der Gesetzgebung. Berlin.

Waaldijk, C. (1984). Het onbruik van de considerans. In 38 Bestuurswetenschappen 406-415.

Waaldijk, C. (1985). Wetgevingswijzer. Lelystad.

Wener, C. (1969). La motivation des décisions administratives en Droit comparé. In Revue International de Droit Comparé 779-795. 